Clemson University

TigerPrints

Publications

Eugene T. Moore School of Education

2021

The Trouble With Binaries: A Perspective on the Science of

Reading

David B. Yaden

David Reinking

Peter Smagorinsky

Follow this and additional works at: https://tigerprints.clemson.edu/eugene_pubs

Part of the Education Commons 


\section{The Trouble With Binaries: A Perspective on the Science of Reading}

David B. Yaden, Jr.

University of Arizona, Tucson, USA

\section{David Reinking}

The University of Georgia, Athens; and Clemson University, South Carolina, USA

\section{Peter Smagorinsky}

The University of Georgia, Athens, USA; and Universidad de Guadalajara, Mexico

\begin{abstract}
In this article, we critique the science of reading when it is positioned within the reading wars as settling disagreements about reading and how it should be taught. We frame our argument in terms of troublesome binaries, specifically between nature and nurture. We interpret that binary in relation to Overton's distinction between split and relational metatheories, with the latter suggesting a more integrative view of nature and nurture. Focusing on the nature side of the binary, which predominates when the science of reading is promoted in the reading wars, we argue that its singular focus limits the range of scientific inquiry, interpretation, and application to practice. Specifically, we address limitations of the science of reading as characterized by a narrow theoretical lens, an abstracted empiricism, and uncritical inductive generalizations derived from brain-imaging and eye movement data sources. Finally, we call for a relational metatheoretical stance and offer emulative examples of that stance in the field.
\end{abstract}

A cross decades, disagreements about how to teach students to read have been framed as the reading wars (Castles, Rastle, \& Nation, 2018; Goldenberg, 2020; Nicholson, 1992; Pearson, 2004). The plurality of the phrase indicates its longevity, and the war metaphor alludes to binaries that define the oppositional perspectives. What is referred to as the science of reading (SOR) has often been positioned among its adherents on one end of the binary as the final arbiter of who can claim victory (see Seidenberg, Cooper Borkenhagen, \& Kearns, 2020). This perspective often views reading specialists in either schools or on teacher education faculties as largely, perhaps deliberately, uninformed about scientific research in reading (Seidenberg, 2017). Some have even argued that the SOR has already settled much of the debate (Castles et al., 2018; Petscher et al., 2020) or made it moot. However, as we argue in this article, what is considered to be the SORits essential character, its scope, and its applicability in matters of teaching reading-also stands on much contested ground.

To open a window for discussion, we focus on a long-standing binary, nature versus nurture, which for our purposes historicizes a fundamentally contested dualism whenever the term science is applied to any human behavior, such as reading and teaching reading (cf. Ellis \& Bloch, 2021; Ellis \& Solms, 2018). It is entwined with and sustained by other binaries, one being the qualitative/quantitative paradigms that guide research methods. On the one hand, the nature side of the binary attends to the biological and neurological processes that produce cognition, with the understanding that "reading is mainly an internal event" 
(Seidenberg et al., 2020, p. S124). On the other hand, the nurture side emphasizes the environmental influences of social, situational, and cultural factors and how thinking processes develop locally (Cole, 1996; Tulviste, 1991). The debate over nature versus nurture has troubled psychologists since Francis Galton coined the phrase in 1869 (1875/2012), and therefore, it is not surprising that its applicability to reading research is only one of countless instantiations in the social sciences.

Our focus, in keeping with the intent of this special issue, is to raise some questions related to the science behind the SOR movement and to the reliability of claims made by those aligned with the nature side of the binary. In this article, we specifically address four limitations that we believe raise questions about the assumptions underlying, and thus conclusions reached, when the SOR is limited to the nature side of the binary and the experimental methods that typically accompany that view: (1) too heavy a reliance on a narrow conception of science claimed to be authoritative and monolithic, (2) too little accounting for environmental factors that complicate the idea that the brain functions identically across the whole of the human population, (3) an exclusive view that experimental designs and replicability are the gold standard of scientific research when other approaches have generated many useful insights, and (4) dismissal of all other conceptions of reading as unscientific and, therefore, of marginal value in generating knowledge about reading and how to teach it.

We discuss these limitations not to dismiss out of hand or to denigrate the findings often put forth from the nature side of the binary. Rather, our inquiry is concerned with the ways in which, within the reading wars, conceptions of the SOR have most frequently been grounded in, and often limited to, individualistic, biological, cognitive, or neurological orientations to understanding mental functions in reading isolated from environmental influences. This focus has persisted despite recent work in the neurosciences (e.g., Dehaene-Lambertz, Monzalvo, \& Dehaene, 2018; Ellis \& Bloch, 2021; Lee, Meltzoff, \& Kuhl, 2020; Noble \& Simon, 2020) using brain-imaging methods that has shown the effects of learning to read and other cultural and social acts on certain brain structures.

Additionally, it is not our intent to unequivocally endorse an equally narrow and exclusive focus on the nurture side of the binary, nor to suggest that it cannot be critically examined. However, in contemporary considerations of the SOR movement, the nurture side of the binary has rarely been acknowledged, cited, or promoted as a legitimate source of findings for understanding and for teaching reading (e.g., Hanford, 2018). It is more commonly the case that findings considered to reflect the SOR, primarily conceived on the nature side of the binary, are promoted as the sine qua non of all considerations of how reading is understood or taught, and are often couched in a rhetoric that gives them unsurpassed prestige and credibility (e.g., Hanford, 2018; Petscher et al., 2020; Seidenberg, 2017).

Thus, our focus on critiquing the nature side of the binary was prompted by its dominance in contemporary considerations of the SOR. However, to restore balance to our critique and to take a more constructive relational, metatheoretical stance, in subsequent sections, we provide an alternative frame for arguing that the two orientations are necessarily related and mutually informative. To illustrate this possibility, we identify some collaborations that deliberately put nature and nurture-neurobiology and social context-in fundamental relation to each other (for further examples, see Nasir, Lee, Pea, \& McKinney de Royston, 2020; Noble \& Simon, 2020). We also acknowledge that many authors writing in the two Reading Research Quarterly special issues on the SOR have recently advocated expanding the SOR terminology to include issues of race and ethnicity (Milner, 2020), second-language learning (Goldenberg, 2020), content knowledge (Cabell \& Hwang, 2020), comprehension (Cervetti et al., 2020), culturally sustaining pedagogy (Vaughn, Parsons, \& Massey, 2020), and research in teacher education (Hoffman, Hikida, \& Sailors, 2020), perspectives with which we are fully aligned.

The organization of our argument begins with a discussion of three primary concepts or premises on which our critique is based: metatheory that provides the general framework for understanding how individual theories in the reading wars can be positioned conceptually, the concept of abstracted empiricism or an uncritical and overreliance on quantitative data, and a distinction between empirical findings taken at face value versus those which have true scientific worth. After this discussion, we present several issues and concerns with findings in the SOR movement that are characterized by its narrow view of science, several inappropriate generalizations from questionable inductions, distorted theorizing from imprecise data gathering and interpretation, and the inconsistency of reliable experimental replication. We conclude our discussion with some promising examples of rapprochement between the neurobiological and social sides, a synthesis of research approaches that appears to be the trend of future literacy research (Lee et al., 2020).

\section{Foundational Concepts and Premises \\ Split Versus Relational Metatheory}

The first foundational concept underpinning our critique involves what is known as metatheory. Metatheories are theories about theories. Overton (2015) argued that metatheories represent "background concepts, which are so termed because, although they establish the framing 
context for the whole paradigm, they seldom explicitly enter into the discourse of any specific set of investigations" (p. 13). These metatheoretical concepts constitute worldviews "that describe and prescribe what is acceptable and unacceptable, meaningful and meaningless as theory-the means of conceptual exploration of any scientific domain - and these rules place constraints on theoretical and observational discourse" (p. 15). In other words, metatheories provide the set of typically unspecified assumptions on which sets of related theories and their own foundational tenets are built (for similar views, see Bateson, 1979; Gould, 2003; Hruby, 2017; Vygotsky, 1987). Thus, metatheories exert great influence over research in guiding what assumptions are made, what questions are asked, what and how studies are conducted, what theories are used and considered relevant, what interpretations and conclusions are offered, and with what sides of various binaries an individual researcher or disciplinary community is aligned.

Overton (2015) distinguished between two broad epistemological worldviews that he called split metatheory and relational metatheory. Split metatheories adhere to a Cartesian mind/body dualism. In terms of the nature/ nurture binary, one pole of the binary privileges internal dimensions such as genetic inheritances, neurological structures, or cognitive processes. The other pole emphasizes contextual factors such as the social environment, family histories, and cultural features.

In contrast, Overton (2015) described relational metatheories as bridging the Cartesian gap. Relational theories avoid the dualistic positioning that underlie the reading wars. Instead, these theories seek to investigate the processes involved in the integration, coordination, and interweaving of internal, biological factors and environmental and social influences in human development.

Dick (2017) situated Overton's (2015) analysis within a developmental framework available in the relational turn underway in various disciplines. Developmental processes involve probabilistic epigenesis that

\footnotetext{
emphasizes the reciprocity of influences within and between levels of an organism's developmental manifold (genetic activity, neural activity, behavior, and the physical, social, and cultural influences of the external environment) and the ubiquity of gene-environment interaction in the realization of all phenotypes. (Gottlieb, 2007, p. 1)
}

According to this perspective, human thinking develops in ways shaped by the biological possibilities provided by nature in relation to the factors available through the environment (Ellis \& Solms, 2018). Neither influence follows a fateful destiny; biology may be affected by interventions (e.g., drugs, surgery, trauma), and environments' shifting forms mediate cognition idiosyncratically.

However, SOR research, for the most part, as it has been employed in the reading wars, has focused almost exclusively on nature and is characteristically a split metatheory. The focus has been on biology, neurological structures, eye movements, and primarily what goes on inside the head and how the typical brain works to decipher written language (cf. Adams, 1990, 2001; Coltheart, 2007; Dehaene, 2009; Kintsch, 2019; Seidenberg, 2017; Shaywitz, 2020; Snowling \& Hulme, 2005; Stanovich, 1986). We address the difficulties of this narrow view in upcoming sections.

\section{The Limits of Abstracted Empiricism}

Another premise of our argument is centered around the exclusion of the environmental, social, and cultural dimensions of literacy from instructional interventions in naturefocused approaches that invites adherence to what the sociologist C. Wright Mills (1959/2000) called abstracted empiricism. Abstracted empiricism refers to exclusive, or disproportionate, emphasis on collecting and analyzing quantifiable data with relatively little emphasis on what the data mean and why they are important, at least beyond an immediate question or issue (see also Kerdeman \& Phillips, 1993). Abstracted empiricism can lead to impoverished theorizing; unfounded, atheoretical extrapolation beyond data; and failure to explicitly acknowledge the assumptions that guide research.

We are concerned that many SOR studies often have remained at the level of abstracted empiricism in interpreting biological findings or testing reading methods experimentally. For example, such work has yet to establish a viable translational theory (for arguments, see Kearns, 2020; Seidenberg et al., 2020; Shanahan, 2020) that connects empirical data from basic brain research with instructional interventions that specify how to teach phonics to first-grade students in different instructional contexts. Indeed, it is debatable whether any such link is actually warranted (cf. Ansari, Coch, \& De Smedt, 2011; Bowers, 2020; Bruer, 1997; Hruby \& Goswami, 2011; Mayer, 2017).

\section{Empiricist Versus Scientific Research}

The final core concept of our argument against narrow interpretations of the SOR derives from Chambers's (1992) distinction between empiricist and scientific research and theory. We argue that the former limits attention only to what can be observed and measured. The demarcation by Chambers of scientific versus empiricist studies directly bears on, we believe, the viability of the SOR in generating useful knowledge. He cited classic examples of how truly revolutionary science entails moving beyond empirical data to infer more overarching understandings, such as the heliocentric view of the universe, the discovery of the structure of the DNA molecule, and the formulation of plate tectonic theory to demonstrate how scientists such as 
Copernicus, Kepler, Wegener, Watson and Crick (and likely Franklin; see Lloyd, 2010), and others were not constrained by what they saw through measuring instruments and the raw data generated. As Chambers observed, it was "not because such savants observed more precisely, but because they penetrated behind the superficial regularity disclosed by the senses" (p. 75).

Further, those investigators' conceptual abstractions were subject to a critique of their assumptions and an expected acknowledgment that they were typically no more than temporary working hypotheses that may generate new insights, further research, and debate about what data to gather and how to interpret those data. The conceptual frames were always expected to be refined and shifted, if not be replaced entirely, by new theoretical frameworks or paradigms (Kuhn, 1962). These are examples of how, historically, science is never settled but, rather, is constantly evolving in relation to new findings that refine or even shift knowledge about phenomena. This evolutionary process is true in both the hard and social sciences, contrary to how science often has been claimed in the SOR movement as having the ability to produce absolute knowledge (Gentry \& Ouellette, 2019; Hanford, 2018; Petscher et al., 2020).

\section{Assessing Selected Claims of the SOR Movement: Some Caveats}

In this section, we introduce several concerns with some common interpretations found in the SOR movement related to brain-imaging and eye movement studies, which then have been uncritically generalized to systematic phonics instruction and other explicit teaching techniques. Woven into our discussion of these concerns are the concepts described earlier-metatheory, abstracted empiricism, and the empiricist/scientific distinctionwith particular emphasis on how they are embedded within results and on how they shape interpretations.

\section{The Tenuous Foundation of Split-Metatheoretical Thinking}

Citations frequently have been made in SOR-oriented publications (e.g., Petscher et al., 2020; Seidenberg, 2017) to the research of cognitive neuroscientist Stanislas Dehaene and colleagues (Dehaene, 2009; Dehaene-Lambertz et al., 2018; Monzalvo \& Dehaene-Lambertz, 2013), who claimed that all brains have a visual word form area or letterbox located in the lower occipital visual cortex that processes letter strings. This brain mechanism "distributes this invariant visual information to numerous regions, spread over the left hemisphere, that encode word meaning, sound pattern, and articulation" (Dehaene, 2009, p. 63). Dehaene's work fits comfortably within split metatheories that posit brain functions as the primary basis for understanding what much evidence, to the contrary, indicates is instead a complex socioneurobiological-cognitive process (Edelman, 1992; Ellis \& Solms, 2018), with the split coming in its focus on the neurobiological and cognitive at the expense of the social (for a compatible view, see Shaywitz, 2020; for critiques of this approach, see Hruby, 2012, 2017).

We lack the space here to enumerate the profound philosophical conundrums associated with determining how three pounds of white, gray, squishy gook the texture of English oatmeal (Searle, as cited in Kreisler, 1999; Searle, 1997) produces consciousness or thinking. Within the neurosciences, however, serious critiques of brainimaging methods have emerged. Many researchers in neurobiology (e.g., Elliott et al., 2020; Hickok, 2014; Lyon, 2017) have voiced alarming concerns about the validity and preciseness of brain imaging techniques such as functional magnetic resonance imaging (fMRI) to detect reliable biomarkers in processes such as reading and in the diagnosis of other mental activity. For example, in a recent meta-analysis of 90 experiments designed to detect various biomarkers in neural activity, Elliott et al. (2020) concluded that "collectively, these findings demonstrate that common task-fMRI measures are not currently suitable for brain biomarker discovery or for individual-differences research" (p. 792). Further, Duke researcher Ahmad Hariri, a member of the Elliott research team, has questioned 15 years' worth of his own publications on MRI, basically revealing that replication studies, even with the same participants, generate different results with not only weak correlations but also poor ones. Hariri went so far as to say, "The bottom line is that task-based fMRI in its current form can't tell you what an individual's brain activation will look like from one test to the next" (as cited in Bates, 2020, para. 10).

In addition, the distinction between empiricist research and extrapolatory scientific research is relevant in considering examples from brain-imaging investigations. These studies use calculated (not raw) data (Hickok, 2014; Roskies, 2007), needing sophisticated, statistical algorithms to generate constructed, composite pictures from multiple, selected fMRI slices, which actually measure subtle changes in the magnetic polarity of water molecules in the brain; in essence, the slices are not equivalent to photographs (Roskies, 2007). Inferences are then uncritically derived from these constructed, multicolored pictures and extrapolated to classroom practices that fit with theories about the relation between neurobiology and action in the world or, in our case, processes of and subsequent instruction in reading. However, Elliott et al.s (2020) statement "that commonly used task-fMRI measures lack the minimal reliability standards" (p. 801) for identifying abnormal brain activity should raise serious caveats in interpreting any imaging study as applicable to classroom applications. 
Other troublesome issues with generalizing from fMRI studies include research on individuals with brain damage showing that neural functions often migrate to other areas (Doidge, 2015) and that, in fact, there is little consensus about how to analyze fMRI data, as different techniques produce different outcomes (Roskies, 2007). Thus, cognitive neuroscientist Gregory Hickok (2014) stated that "despite the clean, pretty pictures we see in journal articles or in the press, it is important to recognize that the data behind those pictures are rather noisy and can be imprecise" (p. 251).

We realize, however, that studying the brain does not preclude attention to factors outside of it. For example, Nobel laureates Edelman (1992) and Kandel (2007) identified relations across a much broader and more complex array of neurological patterning that includes both neural functioning and social and environmental influences that contribute to cognitive processing, including reading (see also Goodman, Fries, \& Strauss, 2016; Noble \& Simon, 2020). These studies have tended to view the brain as one component of the more distributed human mind, which extends beyond the skin (Wertsch \& Tulviste, 1992) and includes tools, sociocultural mediation, and many historical ways of being that shape present cognition, and other external factors from outside the body, particularly from outside the head.

Unfortunately, bodily factors such as illness, neurology, trauma, hunger, and other influences do not figure into the SOR locus for cognition. The brain itself is where the action is, with measures in neuroscience uncritically perceived by the public, legislators, and some researchers to be more precise and informative than behavioral indices (Noble \& Simon, 2020). This perception has spawned the increasing privatization and frequency of dubious educational solutions by for-profit companies (Gabriel, 2020). This narrow, split-metatheoretical attention on the brain elides attention to the sorts of environmental factors that would question so-called best (Reinking, 2007) and high-leverage practices and that would argue instead that what works in classrooms also requires an accounting for the contexts that have shaped students' learning outside school and the factors that shape activity within schools (Smagorinsky, 2009, 2018).

\section{The Limits of Inductive Generalization}

It is important to acknowledge that some form of inductive generalization is essential to everyday living. Life would be unbearably complicated if people could not draw generalized assumptions and predictions from an accumulation of past experience. For instance, people who toss a ball into the air are confident that it will come down. However, as Scottish philosopher David Hume (1739/1985) pointed out nearly three centuries ago, such everyday thinking and the experience of constant conjunction foster a habit of the mind that leads us to, in many cases, uncritically anticipate the conclusion on the occasion of a new instance of the second premise (as cited in Henderson, 2020). Although these habits of mind become engrained through socialization and are foundational to the development and perpetuation of cultures (Shweder, 1991), for good or ill, when they are based on dubious premises, incomplete facts, and biased interpretations, they can produce grave problems in society and in science.

The extent to which abstracted empiricism is operating within the SOR trope employed in the reading wars may also be exacerbated by the ways in which induction works in generalizing from findings that claim a scientific basis. In our view, those who assert that scientific experiments can settle the reading wars might benefit from reconciling that belief with long-standing views about the role of inductive generalization within the domain of science and among those who work in that domain. Even in the hard sciences, several notable philosophers of science have concluded that inductive generalization, even in physics, introduces many dangers for interpretation (e.g., Lakatos, 1968). Further, whereas extensive replication is assumed to sustain inductive generalizations and to explore possible anomalies in experimental investigations, there is a growing body of research demonstrating the relative infrequency of reliable replication in psychology, educational research, and many other fields (see, e.g., Bohannon, 2015; Lemoine et al., 2016; Schmidt \& Oh, 2016; Yong, 2012).

Taleb (2007) described such faulty reasoning as a black swan event, deriving from the belief among Europeans that all swans were white, until they found disconfirming data in Australia in the form of black swans. Vygotsky (1987) called such examples a pseudoconcept, one that generalizes improperly from insufficient information. Developmentally, such misconceptions are inevitable in the growth of children and adolescents but should not, however, form the basis of what is presented as mature scientific thinking that can have high-stakes consequences for students in school.

Ignoring the limitations of abstracted empiricism and inductive generalization can be mutually reinforcing in creating a patina of scientific certainty. Together, they become even more potent, but also more misleading when they are used to suggest causality, at least without some sophisticated statistical manipulations (Pearl, 2014). This problem is illustrated not only with brain-imaging approaches discussed previously but also in research on eye movements. Based on extensive observations, Miles Tinker (1964) convincingly documented differences in the eye movements of good and poor readers as they read texts. However, excluding situational, background, or motivation issues, he then atheoretically generalized his findings of eye movement patterns as representing a causal factor essential to good reading by proposing that 
reading ability could be improved by teaching poor readers to make more efficient eye movements.

Notwithstanding several decades of improvements in eye-tracking measurement and analysis since Tinker's (1964) research, similar noise and imprecision are still characteristic of that body of empirical work. Although frequently cited in the SOR literature (e.g., Adams, 1990, 2001) as demonstrating sequential, letter-by-letter scanning of letters in text, eye movement scan paths are notoriously nonlinear (Holmqvist et al., 2011; Rayner, 1998, 2009), exhibiting frequent regressions, fixations beginning at the middle or ends of words, and multiple, nonsequential fixations on the same words or phrases (Rayner, 2009). Researchers (e.g., Goodman et al., 2016; Rayner, 1998) have consistently found that a substantial number of words are skipped, with a range of $60-85 \%$ of content words being fixated on and only $35 \%$ of function words. There is even a debate as to whether eye movement location is a good index of what a person is actually thinking at a particular time (Holmqvist et al., 2011). These findings ought to raise concern about the sorts of generalizations made from both brain-based reading research or eye tracking and their extrapolations to reading instruction.

\section{The Infrequency and Inconsistency of Replicable Educational Research}

Both confounding and lurking variables pose challenges for every inductive generalization and attempt at replication. This issue has been long recognized in the literature of education research, often under the rubric of attribute/ trait-treatment interactions (Berliner, 2014; Cronbach, 1975) and intersectionality (Crenshaw, 1991). Further, there is evidence that even in the hard sciences, the statistical effects found in often groundbreaking initial findings consistently, yet mysteriously, become more moderate, and sometimes even disappear, over time (for an overview, see Lehrer, 2010).

In a recent analysis of 100 top-tier, peer-reviewed research journals in education, including journals reporting reading research, Makel and Plucker (2014) found that only 13 published studies in 10,000 were replications and that only six journals had published between one and five in 100. The low rate of publishing replications, the authors argued, may be due to editors' and reviewers' reluctance to publish studies that only confirm findings rather than generate new knowledge. Further, Hattie (2009) analyzed over 800 meta-analyses that included more than 50,000 experimental studies of interventions in education across 2 million students. The average effect size was an unimpressive 0.4 , especially given that a bias exists toward publishing statistically significant findings at the level of 0.05 or less and that the set of studies investigated included obviously useful pedagogical practices, such as providing feedback and increasing time on task, which allows much space for considering environmental factors that may be operating.

Further, generalizations about practices based on statistical analyses can be misleading, sometimes due to what is called Simpson's paradox (Pearl, 2014), which characterizes how a generalized finding can be reversed entirely when data are disaggregated into subgroups. For example, a statistical analysis of two treatments for kidney stones favored treatment A over treatment B (Julious \& Mullee, 1994). However, paradoxically, when the data for treatments were separated for large and small kidney stones, treatment B was statistically superior in both cases. In short, disaggregated data can not only muddy the waters but also, in some cases, reverse a generalization (Smyth \& Schorr, 2009).

As Cronbach (1975) stated in what might be called relational metatheoretical language, "when we give proper weight to local conditions, any generalization is a working hypothesis, not a conclusion" (p. 125). Thus, unless new analyses can show that reading research is a notable exception, it is difficult to reconcile these findings with any claim of definitive generalizations from experimental research that settle the reading wars, despite the National Reading Panel's (National Institute of Child Health and Human Development, 2000) belief that only experimental studies have validity in determining best practices in reading instruction.

In this section, we maintained that in the realm of science, the relation between induction and generalization is not a simple, straightforward one, as is often stated or presumed in the SOR, at least as it is conceptualized in the reading wars. Specifically, those who assume, or even claim, that there is a settled SOR, especially one that dictates unequivocally how reading should be taught for all students, are not operating in the spirit, or within the accepted interpretive tradition and practice, of science. Therefore, in the next section, we revisit the concept of metatheory and propose a relational metatheoretical approach to literacy research around which, hopefully, former adversaries in the reading wars can find acceptable compromises.

\section{A Relational Metatheoretical Approach to a SOR}

What might a more inclusive, valid, generative, and educationally productive SOR look like? We believe that at least part of the answer lies in moving away from the binaries that comprise Overton's (2015) split metatheories and moving toward a more integrative stance within relational metatheories. That synthesis requires seeking a collaborative common ground between binaries, including between nature (views of research inspired by the natural and biological sciences) and nurture (conceptions of reading and literacy solely attentive to the environmental, the social, and influences; Ellis \& Solms, 2018). As mentioned earlier, 
such inclusivity for broadening the definition and research base of the SOR has already been advocated by other authors in these two special issues (e.g., Cabell \& Hwang, 2020; Cervetti et al., 2020; Goldenberg, 2020; Hoffman et al., 2020; Milner, 2020; Vaughn et al., 2020).

We believe that there have been relatively few current or past models of what such a rapprochement might look like, but there are some that might be emulated. Vygotsky is a common reference for those on the nurture side of the binary, because his work is typically associated with social factors (Wertsch, 1985). Yet, his focus was not solely on the environment. Indeed, his collaborator Alexander Luria became known for his foundational work in neuropsychology, and even Vygotsky enrolled in medical school late in his illness-shortened career to increase his knowledge of the biological and neurological aspects of development (Levitin, 1982; Luria, 1973). As described by Toulmin, Vygotsky's research team eschewed a Cartesian duality by viewing nature and nurture as inextricably intertwined:

Vygotsky's goal was to discover how enculturation, socialisation, and the development of thought processes are shaped by the child's inner life.... In neurological terms, similarly, he wanted to find out how the social, cultural, linguistic, and intellectual skills [the child] acquires during the formative years are supported by, and "represented in," the cortical mechanisms of the maturing nervous system. (as cited in Levitin, 1982, p. 77)

Vygotsky $(1987,1997)$ argued that human development is a function of the intersection of nature and nurture. He continually stressed that although germane to the developing personality, materialist explanations alone (i.e., biological, neurological, physiological, stimulusresponse mechanisms) of human behavior were never sufficient to explain the higher, culturally mediated psychological functions, such as attitudes, ideologies, methods of abstract reasoning, memory, emotions, voluntary attention, or will. To Vygotsky and the cultural-historical approach that he and his colleagues founded (Cole, 1996), the nature/nurture debate was not an either/or question but a both/and proposition (for a recent statement of this perspective, see Ellis \& Bloch, 2021).

Another good model is Ann Brown, whose foundational work derived from carefully controlled experiments under laboratory-like conditions (e.g., Brown, 1985; Brown \& Smiley, 1977). Yet, equipped with her laboratory data and the theoretical understandings they generated, she spent many years subsequently trying to translate that theory into viable instructional practice, working in classrooms. She meshed her laboratory work with pedagogical perspectives that she found consistent with them, leading to the development of reciprocal teaching and laying a foundation for strategy instruction as an important component of developing reading comprehension ability (e.g., Palincsar \& Brown, 1984). However, Brown wrote about the inadequacies of her laboratory methods in her classroom work where a myriad of factors and potential obstacles figured into theoretically sound and pedagogically viable instruction. Her personal insights led her to describe her work as design experiments. That work became foundational to current design-based research (Reinking, in press), an approach well suited to solving practical problems through rigorous methods for data collection and analysis. It also generates theories directly applicable to pedagogy, much as engineers must be familiar with fundamental theories and research in the physical science but also knowledgeable about how to apply them practically (Brown, 1992).

Two other examples, reminiscent of the fruitful Vygotsky and Luria collaboration in blending nature and nurture, come to mind. First, Margaret Eisenhart, a cultural anthropologist interested in education, and Hilda Borko, an educational psychologist, had a career-long collaboration leading to a book that highlights principles for conducting classroom research that melds their differing perspectives (Eisenhart \& Borko, 1993). Their stated aim was not simply to bring together those perspectives additively but to fully integrate them synergistically. Second, Lee (with a cultural practices orientation), Meltzoff, and Kuhl (with a neurophysiological orientation; 2020) collaborated

to see what we can learn from emerging findings in the neurosciences and the convergence of these ideas in other areas of study, including human development, studies of cognition-incontext, and studies of the socio-emotional consequences of participation in cultural practices. (p. 25)

We believe that it is not coincidental that in several of these examples, the nature/nurture binary was often integrated by working directly in the practical setting of classrooms, rather than in controlled laboratories or in the armchair. If détente is necessary and achievable in the reading wars, it is more likely to be achieved through collaborative work that occurs in classrooms. This integration of the theoretical and practical is concerned with working toward valued pedagogical goals, including the one of interest here: how to help children and youth become more skillful, insightful readers of texts. That view aligns with Dewey's (1929) belief that research and practice are inseparable (see Biesta \& Burbules, 2003; Smagorinsky, 1995). He argued that the quest for certainty is often fruitless in an ambiguous world but that useful knowledge in achieving valued democratic goals can be achieved when knowledge generation is inextricably linked to practice (Reinking \& Yaden, 2020).

\section{Final Comments}

We believe that considering split and relational metatheories reveals the limitations of the SOR movement's narrow 
consideration of what factors and influences explain reading and learning to read. It also underscores the manner in which the SOR movement's view of science and its valorization of quantitative, experimental methods not only are dismissive of critical contextual variables but also generalize from their own data in questionable ways. Specifically, we conclude that viewing science as an accumulation of quantifiable empirical data and unqualified inductive generalizations embeds a number of problems that undermine any claims from that perspective to having exclusive authority in understanding reading and guiding reading instruction. These include the issues that the SOR, as we suggested in the introduction, relies on a limited conception of science, ignores relevant environmental factors, and uncritically accepts experimentation as the only valid approach to social science inquiry in literacy.

We find these issues to be present in the SOR movement, leading to the oversimplification of understanding the nature of the reading process, of teaching reading, and of conducting research into effective reading pedagogies. The conception of science embedded in SOR research reduces reading to a technical exercise that eliminates critical variables that follow from how the vicissitudes of living in a complex physical and social world contribute to how people read, why they read, and how they experience reading instruction. Seidenberg (2017), for example, explicitly dismissed these factors as distractions manufactured by reading teachers and teacher educators that lead away from, rather than inform, an understanding of brain functions as they produce acts of reading. As Smagorinsky (in press) noted, reducing inordinate class sizes, making buildings safe and sanitary, using resources that are current and accessible, and providing learning environments that enable teachers to work securely and effectively would greatly enhance their ability to care for the whole student and the experiences those students bring individually, culturally, and collectively to schools.

Adopting this broader disposition would involve an acknowledgment of the tension between global generalizations and local decision making inherent in statistical analyses (Joyce \& Cartwright, 2020) and the ever-expanding boundary of what constitutes existing knowledge. In designing, analyzing, and interpreting their data, SOR researchers could expand their focus by considering processes as much as outcomes, including those processes involved in the act of reading in relation to the classroom environment and its surroundings, and the many acts involved in learning to teach and, in turn, teaching students how to engage with texts and their various sign systems. Such attention might help move the researchers' work beyond only measurable variables and toward attention to reading contexts. The importance of these local classroom conditions was underscored by Berliner (2014), who reported that highly rated teachers become evaluated as incompetent simply by changes in their student populations.
Because many test measures are insensitive to situational contexts, conclusions derived solely from measurable outcomes as applied to general populations should be viewed with extreme skepticism.

Unfortunately, we believe that in many cases, the cloak of science has been employed to elevate the stature of SOR work and to promote the certainty and force of its advocates' preferred explanations for what reading is and how it should be taught (e.g., Gentry \& Ouellette, 2019; Schwartz \& Sparks, 2019). What we suggested in this article is that the SOR, when so used in the reading wars, is not science at all in its fullest sense. It neglects an entire domain that influences and shapes human experience. It does so with an unmitigated confidence that evidence from one side of a binary can establish a final truth and that such a truth creates a single prescription for all instruction. Taking that stance, however, is outside the pale of science and dismisses work that has both merit on its own terms and a critical role in advancing the aims motivating reading research and instruction.

\section{REFERENCES}

Adams, M.J. (1990). Beginning to read: Thinking and learning about print. Cambridge, MA: MIT Press.

Adams, M.J. (2001). Alphabetic anxiety and explicit, systematic phonics instruction: A cognitive science perspective. In S.B. Neuman \& D.K. Dickinson (Eds.), Handbook of early literacy research (Vol. 1, pp. 66-80). New York, NY: Guilford.

Ansari, D., Coch, D., \& De Smedt, B. (2011). Connecting education and cognitive neuroscience: Where will the journey take us? Educational Philosophy and Theory, 43(1), 37-42. https://doi.org/10.1111/j.14695812.2010.00705.x

Bates, K.L. (2020, June). Studies of brain activity aren't as useful as scientists thought. Duke Today. Retrieved from https://today.duke. edu/2020/06/studies-brain-activity-aren\%E2\%80\%99t-useful-scien tists-thought

Bateson, G. (1979). Mind and nature: A necessary unity. New York, NY: E.P. Dutton.

Berliner, D.C. (2014). Exogenous variables and value-added assessments: A fatal flaw. Teachers College Record, 116(1), 1-31.

Biesta, G.J.J., \& Burbules, N.C. (2003). Pragmatism and educational research. Lanham, MD: Rowman \& Littlefield.

Bohannon, J. (2015). Many psychology papers fail replication test. Science, 349(6251), 910-911. https://doi.org/10.1126/science.349.6251.910

Bowers, J.S. (2020). Reconsidering the evidence that systematic phonics is more effective than alternative methods of reading instruction. Educational Psychology Review, 32, 681-705. https://doi.org/10.10 07/s10648-019-09515-y

Brown, A.L. (1985). Teaching students to think as they read: Implications for curriculum Reform (Reading Education Report No. 58). Retrieved from ERIC database. (ED273567)

Brown, A.L. (1992). Design experiments: Theoretical and methodological challenges in creating complex interventions in classroom settings. Journal of the Learning Sciences, 2(2), 141-178. https://doi. org/10.1207/s15327809jls0202_2

Brown, A.L., \& Smiley, S.S. (1977). Rating the importance of structural units of prose passages: A problem of metacognitive development. Child Development, 48(1), 1-8. https://doi.org/10.2307/1128873

Bruer, J.T. (1997). Education and the brain: A bridge too far. Educational Researcher, 26(8), 4-16. https://doi.org/10.3102/0013189X02 6008004 
Cabell, S.Q., \& Hwang, H.-J. (2020). Building content knowledge to boost comprehension in the primary grades. Reading Research Quarterly, 55(S1), S99-S107. https://doi.org/10.1002/rrq.338

Castles, A., Rastle, K., \& Nation, K. (2018). Ending the reading wars: Reading acquisition from novice to expert. Psychological Science in the Public Interest, 19(1), 5-51. https://doi.org/10.1177/1529100618 772271

Cervetti, G.N., Pearson, P.D., Palincsar, A.S., Afflerbach, P., Kendeou, P., Biancarosa, G., ... Berman, A.I. (2020). How the Reading for Understanding initiative's research complicates the simple view of reading invoked in the science of reading. Reading Research Quarterly, 55(S1), S161-S172. https://doi.org/10.1002/rrq.343

Chambers, J.H. (1992). Empiricist research on teaching: A philosophical and practical critique of its scientific pretensions. New York, NY: Kluwer Academic.

Cole, M. (1996). Cultural psychology: A once and future discipline. Cambridge, MA: Harvard University Press.

Coltheart, M. (2007). Modeling reading: The dual-route approach. In M. Snowling \& C. Hulme (Eds.), The science of reading: A handbook (pp. 6-23). Malden, MA: Blackwell.

Crenshaw, K. (1991). Mapping the margins: Intersectionality, identity politics, and violence against women of color. Stanford Law Review, 43(6), 1241-1299. https://doi.org/10.2307/1229039

Cronbach, L.J. (1975). Beyond the two disciplines of scientific psychology. The American Psychologist, 30(2), 116-127. https://doi.org/10. $1037 / \mathrm{h} 0076829$

Dehaene, S. (2009). Reading in the brain: The new science of how we read. New York, NY: Penguin.

Dehaene-Lambertz, G., Monzalvo, K., \& Dehaene, S. (2018). The emergence of the visual word form: Longitudinal evolution of category-specific ventral visual areas during reading acquisition. PLOS Biology, 16(3), Article e2004103. https://doi.org/10.1371/ journal.pbio.2004103

Dewey, J. (1929). The quest for certainty: A study of the relation of knowledge and action. New York, NY: Capricorn.

Dick, A.S. (2017). The ontogenesis of neural networks from a network science perspective. In A.S. Dick \& U. Müller (Eds.), Advancing developmental science: Philosophy, theory, and method (pp. 65-78). New York, NY: Routledge.

Doidge, N. (2015). The brain's way of healing: Remarkable discoveries and recoveries from the frontiers of neuroplasticity. New York, NY: Penguin.

Edelman, G.M. (1992). Bright air, brilliant fire: On the matter of mind. New York, NY: Basic.

Eisenhart, M., \& Borko, H. (1993). Designing classroom research: Themes, issues, and struggles. Needham, MA: Allyn \& Bacon.

Elliott, M.L., Knodt, A.R., Ireland, D., Morris, M.L., Poulton, R., Ramrakha, S., ... Hariri, A.R. (2020). What is the test-retest reliability of common task-functional MRI measures? New empirical evidence and a meta-analysis. Psychological Science, 31(7), 792-806. https:// doi.org/10.1177/0956797620916786

Ellis, G., \& Bloch, C. (2021). Neuroscience and literacy: An integrative view. Quantitative Biology. Advance online publication. https:// arxiv.org/abs/2012.03240

Ellis, G., \& Solms, M. (2018). Beyond evolutionary psychology: How and why neuropsychological modules arise. Cambridge, UK: Cambridge University Press.

Gabriel, R. (2020). Converting to privatization: A discourse analysis of dyslexia policy initiatives. American Educational Research Journal, 57(1), 305-338. https://doi.org/10.3102/0002831219861945

Galton, F. (2012). The history of twins, as a criterion of the relative powers of nature and nurture. International Journal of Epidemiology, 41(4), 905-911. https://doi.org/10.1093/ije/dys097 (Original work published 1875)

Gentry, J.R., \& Ouellette, G.P. (2019). Brain words: How the science of reading informs teaching. Portsmouth, $\mathrm{NH}$ : Stenhouse.
Goldenberg, C. (2020). Reading wars, reading science, and English learners. Reading Research Quarterly, 55(S1), S131-S144. https://doi. org/10.1002/rrq.340

Goodman, K.S., Fries, P.H., \& Strauss, S.L. (2016). Reading: The grand illusion: How and why people make sense of print. New York, NY: Routledge.

Gottlieb, G. (2007). Probabilistic epigenesis. Developmental Science, 10(1), 1-11. https://doi.org/10.1111/j.1467-7687.2007.00556.x

Gould, S.J. (2003). The hedgehog, the fox, and the magister's pox: Mending the gap between science and the humanities. New York, NY: Three Rivers.

Hanford, E. (2018, October 26). Why are we still teaching reading the wrong way? The New York Times. Retrieved from https://www. nytimes.com/2018/10/26/opinion/sunday/phonics-teaching-readingwrong-way.html

Hattie, J. (2009). Visible learning: A synthesis of over 800 meta-analyses relating to achievement. New York, NY: Routledge.

Henderson, L. (2020). The problem of induction. In E.N. Zalta (Ed.), Stanford encyclopedia of philosophy. Retrieved from https://plato. stanford.edu/archives/spr2020/entries/induction-problem/

Hickok, G. (2014). The myth of mirror neurons: The real neuroscience of communication and cognition. New York, NY: W.W. Norton.

Hoffman, J.V., Hikida, M., \& Sailors, M. (2020). Contesting science that silences: Amplifying equity, agency, and design research in literacy teacher preparation. Reading Research Quarterly, 55(S1), S255-S266. https://doi.org/10.1002/rrq.353

Holmqvist, K., Nyström, M., Andersson, R., Dewhurst, R., Jarodzka, H., \& van de Weijer, J. (2011). Eye tracking: A comprehensive guide to methods and measures. Oxford, UK: Oxford University Press.

Hruby, G.G. (2012). Three requirements for justifying an educational neuroscience. British Journal of Educational Psychology, 82(1), 1-23. https://doi.org/10.1111/j.2044-8279.2012.02068.x

Hruby, G.G. (2017). Literacy, comprehension, and the neurosciences. In S.E. Israel (Ed.), Handbook of research on reading comprehension (2nd ed., pp. 191-216). New York, NY: Guilford.

Hruby, G.G., \& Goswami, U. (2011). Neuroscience and reading: A review for reading education researchers. Reading Research Quarterly, 46(2), 156-172. https://doi.org/10.1598/RRQ.46.2.4

Hume, D. (1985). A treatise on human nature. New York, NY: Penguin. (Original work published 1739)

Joyce, K.E., \& Cartwright, N. (2020). Bridging the gap between research and practice: Predicting what will work locally. American Educational Research Journal, 57(3), 1045-1082. https://doi.org/10.3102/ 0002831219866687

Julious, S.A., \& Mullee, M.A. (1994). Confounding and Simpson's paradox. British Medical Journal, 309(6967), 1480-1481. https://doi. org/10.1136/bmj.309.6967.1480

Kandel, E. (2007). In search of memory: The emergence of a new science of mind. New York, NY: W.W. Norton.

Kearns, D.M. (2020). Does English have useful syllable division patterns? Reading Research Quarterly, 55(S1), S145-S160. https://doi. org/10.1002/rrq.342

Kerdeman, D., \& Phillips, D.C. (1993). Empiricism and the knowledge base of educational practice. Review of Educational Research, 63(3), 305-313. https://doi.org/10.3102/00346543063003305

Kintsch, W. (2019). Revisiting the construction-integration model of text comprehension and its implications for instruction. In D.E. Alvermann, N.J. Unrau, M. Sailors, \& R.B. Ruddell (Eds.), Theoretical models and processes of literacy (7th ed., pp. 178-203). New York, NY: Routledge.

Kreisler, H. (1999). Philosophy and the habits of critical thinking: A conversation with John R. Searle. Retrieved from http://globetrotter. berkeley.edu/people/Searle/searle-con2.html

Kuhn, T.S. (1962). The structure of scientific revolutions. Chicago, IL: University of Chicago Press. 
Lakatos, I. (Ed.). (1968). Proceedings of the International Colloquium in the Philosophy of Science, London, 1965: Vol. 2. The problem of inductive logic. Amsterdam, Netherlands: North-Holland.

Lee, C.D., Meltzoff, A.N., \& Kuhl, P.K. (2020). The braid of human learning and development: Neuro-physiological processes and participation in cultural practices. In N.S. Nasir, C.D. Lee, R. Pea, \& M. McKinney de Roysten (Eds.), Handbook of the cultural foundations of learning (pp. 24-43). New York, NY: Routledge.

Lehrer, J. (2010, December 5). The truth wears off: Is there something wrong with the scientific method? The New Yorker. Retrieved from https://www.newyorker.com/magazine/2010/12/13/the-truth-wearsoff

Lemoine, N.P., Hoffman, A., Felton, A.J., Baur, L., Chaves, F., Gray, J., ... Smith, M.D. (2016). Underappreciated problems of low replication in ecological field studies. Ecology, 97(10), 2554-2561. https://doi. org/10.1002/ecy.1506

Levitin, K. (1982). One is not born a personality: Profiles of Soviet education psychologists (V.V. Davydov, Ed.; Y. Filippov, Trans.). Moscow, Russia: Progress.

Lloyd, R. (2010, November 3). Rosalind Franklin and DNA: How wronged was she? [Web log post]. Retrieved from https://blogs. scientificamerican.com/observations/rosalind-franklin-and-dna-howwronged-was-she/

Luria, A.R. (1973). The working brain: An introduction to neuropsychology (B. Haigh, Trans.). New York, NY: Basic.

Lyon, L. (2017). Dead salmon and voodoo correlations: Should we be skeptical about functional MRI? Brain, 140(8), Article e53. https:// doi.org/10.1093/brain/awx180

Makel, M.C., \& Plucker, J.A. (2014). Facts are more important than novelty: Replication in the education sciences. Educational Researcher, 43(6), 304-316. https://doi.org/10.3102/0013189X14545513

Mayer, R.E. (2017). How can brain research inform academic learning and instruction? Educational Psychology Review, 29(4), 835-846. https://doi.org/10.1007/s10648-016-9391-1

Mills, C.W. (2000). The sociological imagination. Oxford, UK: Oxford University Press. (Original work published 1959)

Milner, H.R., IV. (2020). Disrupting racism and whiteness in researching a science of reading. Reading Research Quarterly, 55(S1), S249-S253. https://doi.org/10.1002/rrq.347

Monzalvo, K., \& Dehaene-Lambertz, G. (2013). How reading acquisition changes children's spoken language network. Brain and Language, 127(3), 356-365. https://doi.org/10.1016/j.bandl.2013.10.009

Nasir, N.S., Lee, C.D., Pea, R., \& McKinney de Roysten, M. (Eds.). (2020). Handbook of the cultural foundations of learning. New York, NY: Routledge.

National Institute of Child Health and Human Development. (2000). Report of the National Reading Panel. Teaching children to read: An evidence-based assessment of the scientific research literature on reading and its implications for reading instruction: Reports of the subgroups (NIH Publication No. 00-4754). Washington, DC: U.S. Government Printing Office.

Nicholson, T. (1992). Reading wars: A brief history and an update. International Journal of Disability Development and Education, 39(3), 173-184. https://doi.org/10.1080/0156655920390302

Noble, K.G., \& Simon, K.R. (2020). How can neuroscience bridge the gap in reading research? In E.B. Moje, P.P. Afflerbach, P. Enciso, \& N.K. Leaux (Eds.), Handbook of reading research (Vol. 5, pp. 487-491). New York, NY: Routledge.

Overton, W.F. (2015). Processes, relations, and relationaldevelopmental-systems. In W.F. Overton \& P.C.M. Molenaar (Eds.), Handbook of child psychology and developmental science: Vol. 1. Theory and method (7th ed., pp. 9-62). Hoboken, NJ: John Wiley \& Sons.

Palincsar, A.S., \& Brown, A.L. (1984). Reciprocal teaching of comprehension-fostering and comprehension-monitoring activities. Cognition and Instruction, 1(2), 117-175. https://doi.org/10.1207/ s1532690xci0102_1
Pearl, J. (2014). Understanding Simpson's paradox. The American Statistician, 68(1), 8-13. https://doi.org/10.1080/00031305.2014.876829

Pearson, P.D. (2004). The reading wars. Educational Policy, 18(1), 216252. https://doi.org/10.1177/0895904803260041

Petscher, Y., Cabell, S.Q., Catts, H.W., Compton, D.L., Foorman, B.R., Hart, S.A., ... Wagner, R.K. (2020). How the science of reading informs 21st-century education. Reading Research Quarterly, 55(S1), S267-S282. https://doi.org/10.1002/rrq.352

Rayner, K. (1998). Eye movements in reading and information processing: 20 years of research. Psychological Bulletin, 124(3), 372-422. https://doi.org/10.1037/0033-2909.124.3.372

Rayner, K. (2009). The 35th Sir Frederick Bartlett Lecture: Eye movements and attention in reading, scene perception and visual search. Quarterly Journal of Experimental Psychology, 62(8), 1457-1506. https://doi.org/10.1080/17470210902816461

Reinking, D. (2007). Toward a good or better understanding of best practice. Journal of Curriculum and Instruction, 1(1), 75-88. https:// doi.org/10.3776/joci.2007.v1n1p75-88

Reinking, D. (in press). Foreword. In Z.A. Philippakos, E. Howell, \& A. Pellegrino (Eds.), Design-based research in education: Theory and applications. New York, NY: Guilford.

Reinking, D., \& Yaden, D.B., Jr. (2020). Do we need more productive theorizing? A commentary. Reading Research Quarterly. Advance online publication. https://doi.org/10.1002/rrq.318

Roskies, A.L. (2007). Are neuroimages like photographs of the brain? Philosophy of Science, 74(5), 860-872. https://doi.org/10.1086/ 525627

Schmidt, F.L., \& Oh, I.-S. (2016). The crisis of confidence in research findings in psychology: Is lack of replication the real problem? Or is it something else? Archives of Scientific Psychology, 4(1), 32-37. https://doi.org/10.1037/arc0000029

Schwartz, S., \& Sparks, S.D. (2019, October 2). How do kids learn to read? What the science says. Education Week. Retrieved from https://www.edweek.org/teaching-learning/how-do-kids-learn-toread-what-the-science-says/2019/10

Searle, J.R. (1997). The mystery of consciousness. New York, NY: New York Review of Books.

Seidenberg, M. (2017). Language at the speed of sight: How we read, why so many can't, and what can be done about it. New York, NY: Basic.

Seidenberg, M.S., Cooper Borkenhagen, M., \& Kearns, D.M. (2020). Lost in translation? Challenges in connecting reading science and educational practice. Reading Research Quarterly, 55(S1), S119-S130. https://doi.org/10.1002/rrq.341

Shanahan, T. (2020). What constitutes a science of reading instruction? Reading Research Quarterly, 55(S1), S235-S247. https://doi.org/10. 1002/rrq.349d

Shaywitz, S.E. (2020). Overcoming dyslexia: A new and complete sciencebased program for reading problems at any level (2nd ed.). Vancouver, WA: Vintage.

Shweder, R.A. (1991). Thinking through cultures: Expeditions in cultural psychology. Cambridge, MA: Harvard University Press.

Smagorinsky, P. (1995). The social construction of data: Methodological problems of investigating learning in the zone of proximal development. Review of Educational Research, 65(3), 191-212. https://doi. org/10.3102/00346543065003191

Smagorinsky, P. (2009). Is it time to abandon the idea of "best practices" in the teaching of English? English Journal, 98(6), 15-22.

Smagorinsky, P. (2018). Literacy teacher education: "It's the context, stupid". Journal of Literacy Research, 50(3), 281-303. https://doi. org/10.1177/1086296X18784692

Smagorinsky, P. (in press). The great equalizer of the conditions of [humanity]: How transformative can schools be when society itself remains inequitable and quarrelsome? In D.C. Berliner \& C. Hermanns (Eds.), Public education: The cornerstone of American democracy. New York, NY: Teachers College Press. 
Smyth, K.F., \& Schorr, L.B. (2009). A lot to lose: A call to rethink what constitutes "evidence" in finding social interventions that work (Working paper). Cambridge, MA: Michael Wiener Center for Social Policy, Harvard Kennedy School. Retrieved from https://ncwwi.org/files/ Evidence_Based_and_Trauma-Informed_Practice/A_Lot_to_Lose.pdf Snowling, M.J., \& Hulme, C. (Eds.). (2005). The science of reading: A handbook. Malden, MA: Blackwell.

Stanovich, K.E. (1986). Matthew effects in reading: Some consequences of individual differences in the acquisition of literacy. Reading Research Quarterly, 21(4), 360-407.

Taleb, N.N. (2007). The black swan: The impact of the highly improbable. New York, NY: Random House.

Tinker, M.A. (1964). Legibility of print. Ames: Iowa State University Press.

Tulviste, P. (1991). The cultural-historical development of verbal thinking (M.J. Hall, Trans.). Hauppauge, NY: Nova Science.

Vaughn, M., Parsons, S.A., \& Massey, D. (2020). Aligning the science of reading with adaptive teaching. Reading Research Quarterly, 55(S1), S299-S306. https://doi.org/10.1002/rrq.351

Vygotsky, L.S. (1987). The collected works of L. S. Vygotsky: Vol. 1. Problems of general psychology (R.W. Rieber \& A.S. Carton, Eds.; N. Minick, Trans.). New York, NY: Plenum.

Vygotsky, L.S. (1997). The collected works of L. S. Vygotsky: Vol. 3. Problems of the theory and history of psychology (R.W. Rieber \& J. Wollock, Eds.; R. Van der Veer, Trans.). New York, NY: Plenum.

Wertsch, J.V. (1985). Vygotsky and the social formation of mind. Cambridge, MA: Harvard University Press.

Wertsch, J.V., \& Tulviste, P. (1992). L. S. Vygotsky and contemporary developmental psychology. Developmental Psychology, 28(4), 548557. https://doi.org/10.1037/0012-1649.28.4.548

Yong, E. (2012). Replication studies: Bad copy. Nature, 485(7398), 298300. https://doi.org/10.1038/485298a
Submitted July 22, 2020

Final revision received March 10, 2021

Accepted March 11, 2021

DAVID B. YADEN, JR. (corresponding author) is a professor in the Department of Teaching, Learning and Sociocultural Studies at the University of Arizona, Tucson, USA; email dyadenjr@arizona.edu. His primary research interests are early childhood development, literacy and biliteracy in young students, epistemological issues in literacy studies, and the application of complex adaptive systems theory to growth in reading and writing.

DAVID REINKING is semiretired, currently with a courtesy appointment in the Department of Language and Literacy Education at The University of Georgia, Athens, and also a Distinguished Professor in the Emeritus College at Clemson University, South Carolina, USA; email david.reinking@uga. edu. He employs design-based research to understand how interventions promoting digital literacy can be integrated into literacy instruction to achieve valued pedagogical goals.

PETER SMAGORINSKY is Distinguished Research Professor Emeritus in the Department of Language and Literacy Education at The University of Georgia, Athens, USA, and Distinguished Visiting Scholar at the Universidad de Guadalajara, Mexico; email smago@uga.edu. His research has applied sociocultural theory to a variety of areas involved in the teaching and learning of literacy and neurodiversity.

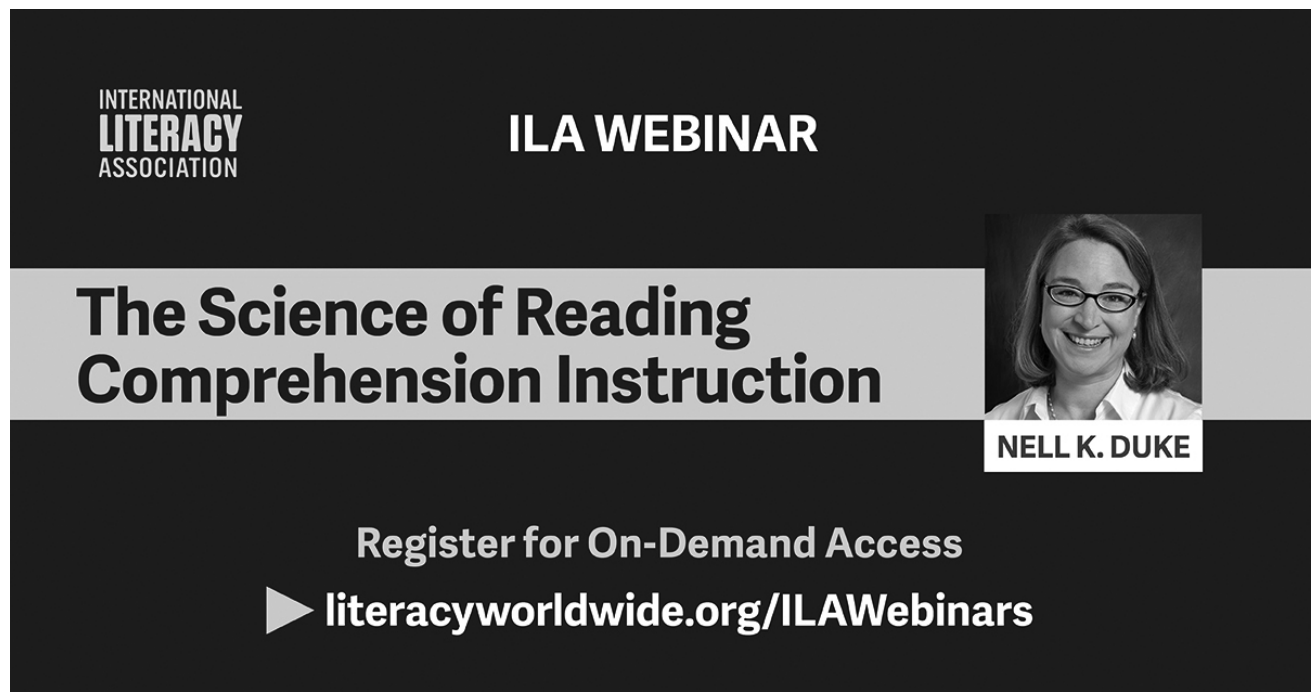

